\title{
Dividend Policy in Indonesian Companies: Does Corporate Governance Matter?
}

\author{
Zaitul, Muhammad Ridwan, Hanna Pratiwi
}

\begin{abstract}
This study investigates whether corporate governance matters with regards to the dividend policy in Indonesian companies. Previous studies on this subject have mostly been done in developed countries, which have adopted the common law, such as in the US and the UK. This study uses 26 companies operating in the finance industry. Secondary data is used from several sources, such as the annual report and financial statement and related websites. This study uses an independent sample t-test to analyse the data. Corporate governance matters for dividend policy in Indonesian companies. It is evidenced by the fact that there is a significant differ ence in managerial ownership and board size between dividend paid and dividend not paid. Profitability also differs between dividend paid and dividend not paid companies; companies with higher profitability tend to pay dividend. This study provides empirical evidence that corporate governance matters for dividend policy in Indonesian companies. There are two contributions of this study: the result confirms the resource dependence theory and the convergence governance hypothesis.
\end{abstract}

Index Terms: Corporate Governance, Dividend Policy, Indonesia.

\section{BACKGROUND OF THE STUDY}

Dividend policy refers to the policy that cash dividend should be paid instead of being retained. The dividend policy optimalization charges a balance between current dividends and future growth and maximizes a company's stock price. The dividend policy has been a finance puzzle and a controversial issue among researchers [1]. Since the seminal work of [2], explanation of the dividend- firmm value relevancy has been offered by several scholars. They relaxed the assumptions of the MM theory (e.g., no taxes and no transaction cost), and concluded that information asymmetry, transaction cost and taxes can be considered as factors that affect dividend policy [3]. For example, [4] argued that managers convey information about the company profitability's to the market through dividend changes. This contention is also supported by [5] and [6]. Therefore, information asymmetry between management and shareholders could be mitigated by dividend policy.

[7] argued that one of the mechanisms often used to mitigate agency cost is dividend policy. Therefore, the dividend policy is a tool to minimize agency and transaction

Revised Manuscript Received on September 22, 2019.

Zaitul, Economics Faculty, Universitas Bung Hatta, Indonesia, zaitul@ bunghatta.ac.id

Muhammad Ridwan, Economics Faculty, Universitas Putra Indonesia YPTK, Indonesia

Hanna Pratiwi, Economics Faculty, Universitas Putra Indonesia YPTK, Indonesia. costs. Further, [8] stated that the dividend policy can reduce the flow of free cash that could alternatively be exhausted by managers for their own benefit. In fact, [9] argued that payment of dividends to the shareholders make a manager to go to the capital market to raise capital more frequently and this behaviour increases monitoring by the capital market. [10] investigated the effect of corporate governance mechanisms (insider ownership and concentration ownership) on dividend policy. [11] argued that corporate governance quality is linked to the company's dividend policy and concluded that a company with better corporate governance is positively related to higher dividend pay-out. This argument is that the stockholders will press the agents to pay dividend from the excess cash flow rather than allow it to be utilized for the manager's private advantaget. However, the effect of good corporate governance on dividend pay-out could be negative. Governance quality should be a substitute for dividend payment in the sense that a firm with better governance is linked to agency cost. Further, [11] and [12] argued that managers are likely to use dividend as a device to mitigate the agency conflict between managers and shareholders. However, the decision to pay or not pay dividend does not always depend on the manager, but also depends on other factors, such as legal environment, regulations, institutional setting and other macro-economic factors [13].

[11] Documented integration between dividend policy and governance structure by using research object from crosscountries and they found that firms in Anglo-Saxon countries pay superior dividends compared to the countries under Continental European Corporate Covernance system, where minority shareholders suffer from weaker legal protection. Thus, policy of dividend may work for a device to protect investors against management and large shareholders' expropriation. In addition, reference [14] investigated the effect of corporate governance and dividend policy. They concluded that companies with better corporate governance have lower dividend pay-out ratio. Despite several previous studies on dividend policy, [15] argued that dividend policy remains an unresolved issue in corporate finance. In addition, most previous studies have been conducted in developed countries, such as the US and the UK. [16] argued that there is a critical need for more research based on the local context to get more understanding on how corporate governance works in different settings.

[17] argued that dividend plays an important role in Indonesia's companies.

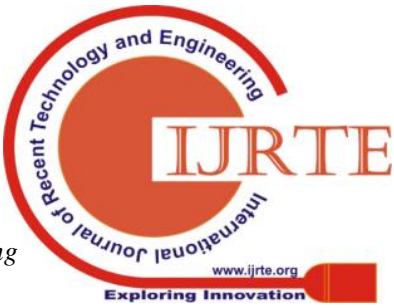


Government plays an important role by having more than 164 companies due to a maerket base economy [17]. [18] assessed the quality of corporate governance in several countries. They noted that Indonesia's corporate governance quality is the second lowest after Korea; and Singapore has the highest score. In fact, Indonesia's competitiveness has a low ranking. In terms of the corporate governance system, Indonesia has adapted the Continental European System. [19] argued that there is a difference between the original Continental European and Indonesia's Corporate Governance Systems. Therefore, a study using data from Indonesia will contribute to the literature on corporate governance, especially its relationship with dividend policy. Therefore, this study investigates whether or not there are any differences in corporate governance between dividend paid and dividend not paid in Indonesia companies. Further, this study investigates the difference between firms that pay and do not pay dividend. This paper is organised as follows: background of the study is the first section. The next part is on the theoretical aspect. It then discusses the methodology of the current study. The result and discussion are in the fourth section and finally, the conclusion and recommendations are given.

\section{THEORETICAL ASPECT}

\section{A. Dividend Policy}

The relationship between dividend policy and corporate governance has drawn the attention of numerous scholars. There are several theories which explain why some companies pay dividend and others do not. [2] are the first scholars to be concerned with the dividend policy and introduced the theory of dividend irrelevance. [2] argued that firm value is influenced only by its business risk and its basic earning power. In addition, the firm value relys on the income created by its assets; not on how this income is distribute to dividends and retained earnings. However, other scholars have relaxed the assumption of the MM theory and concluded that a firm's value will be maximised by setting a high dividend pay-out ratio; this is known as the bird-in- the-hand theory [20,21]. Further, the tax preference theory has been introduced to explain why some investors prefer a low dividend pay-out ratio and why the relationship between dividend policy and a firm's value is negative. The most important conclusion regarding the above theories is that dividend policy is significantly related to firm's value.

The agency theory [7] is one of the underpinning theories that explains why a company pays dividends. Under this theory, agency conflict leads to agency cost due to the separation between ownership and control. With regards to the dividend policy, the principal will force agents to disgorge cash out of the firm, thus reducing free cash flow that management wastes or invests in a project with low internal rate of returns (IRR) [8,9]. There are two opposing hypotheses regarding the relationship between agency problem and dividend policy: Outcome Hypothesis vs. Substitute Hypothesis [11]. First, the outcome hypothesis posits that companies with weak corporate governance tend to retain earnings in order to allow them to invest in projects and acquisitions, use up perquisites and involve in empire building that may increase their personal dignity but they do not provide stockholder with sufficient benefits. However, managers are less likely to misuse the flow of free cash, thus increasing the elegancy of paying out cash to stockholders in a company with good practice of corporate governance. Second, the substitute hypothesis concludes that a larger dividend substitutes for weaker corporate governance. In other words, a company with poor corporate governance will pay more dividend and vice versa.

Previous studies that support the outcome hypothesis include [11, 22-25]. Using data from 117 Canadian companies listed on the Toronto Stock Exchange, [22] found that managers use the dividend policy to protect shareholders and to reduce agency cost. [23] found corporate governance has a significant effect on dividend policy for 1,096 SMEs in the UK. [24] concluded that firms with a higher creditor rights protection (good corporate governance) are more likely to pay higher dividend. Further, [25] documented that firms with strong shareholders have higher dividend pay-out. With regards to the substitute hypothesis, [26] argued that firms with higher managerial ownership tend to pay more dividend. In addition, [27] concluded that firms with good growth prospects in countries with weak legal investor protection, pay higher dividend.

\section{B. Corporate Governance}

The importance of good corporate governance for making financial decisions, such as dividend policy, has been mentioned by many scholars. The agency theory (Jensen \& Meckling, 1976) is the main theory used to explain what factors affect dividend policy. The term, 'corporate governance' has been mentioned by Berle \& Means from as early as 1932. In addition, corporate governance has been defined by many scholars and institutions. For example, [11] defined corporate governance as a set of procedures in order to protect the interests of outside shareholders from the company's insiders. Corporate governance is also defined as the whole system of controls, both financial and otherwise, by which a company is directed and controlled, as quoted by Cadbury Report. The OECD defines corporate governance as a set of connections among the Board of Directors, shareholders and other stakeholders.

Indonesia's Corporate Governance System is adapted from the Continental European System. Indonesia's corporate governance characteristics are marked by weak legal enforcement, concentrated ownership, family-based ownership and ownership through business groups and involving the controlling shareholders in supervisory and management boards [11]. [29] categorised Indonesia's culture as a low trust society which therefore influences the corporate governance structure, such as ownership and board structures. According to [11], Indonesian companies should pay lower dividend since Indonesia's Corporate Governance System follows

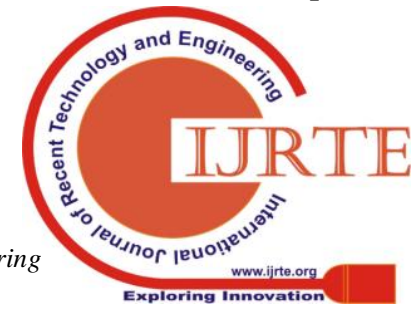


the Continental European System which originated from French civil law.

Information asymmetry arises between agent and principal due to the separation of ownership and control, thus increasing agency problems and cost [7]. To resolve agency problems and cost, corporate governance mechanisms could be used. These mechanisms can assure shareholders that managers will act based on the shareholders' interest. There are two corporate governance mechanisms: external and internal mechanisms. [30] said that the internal mechanism could be in the form of Board of Directors and ownership. [31] explained that the Board of Directors plays an important role in mitigating agency problems. In addition, the Board of Directors has authority and control to check the implementation of corporate policies by managers [32].

The role of board independence in mitigating agency problems may be explained using the Resource Dependence Theory. [33] said that outside directors often help a company secure resources through their external associations. In addition, [34] stated that directors can draw resources for successful company operations. [35] concluded that company with a high proportion of non- executive directors tends to upgrade the company board independency. [36] posited that there is a positively significant association between board independence and dividend policy. Further, [15] studied 714 Canadian companies from 2002-2005.

They found a positive effect of board independence on dividend policy. [3] also found a positive relationship between board independence and dividend policy using Australian companies. However, [37] concluded that there is a negative association between dividend policy and board independence. Board size refers to the total number of board members carrying out the monitoring function. There are two conflicting views regarding board size. First, a small board is more effective in monitoring management decisions [38] as it reduces the problem of communication and the decision-making process. The second view stems from the resource dependence theory [33], which suggests that a large board provides the company with diversity in terms of expertise, experience and knowledge of its members. Very few studies have investigated the impact of board size on dividend policy. A prior study by [36] used companies from Sub-Saharan Africa. They concluded that there is a positive relationship between board size and dividend policy. From the discussions above, we predict that there is a positive relationship between board size and dividend policy.

As mentioned above, another internal mechanism of corporate governance is ownership. The agency theory proposes that management should have a small portion of company stocks in order to have an interest on net income and this interest must be aligned with shareholders' interest [39]. However, the ownership portion must not exceed the limit such that it may lead managers to opt for the accounting decision which benefits their personal interest and influences the motive to maximize firm value $[39,40]$.
[26] investigated the relationship between dividend policy, and incentive of magerial incentive and concluded that agency costs are mitigated by managerial stock incentive for firms with surplus cash flow problems. [41] also investigated dividend policy and managerial ownership and conclude that there is a negative association between managerial ownership and dividend policy. Based on the theory and previous studies, it can be predicted that:

$\mathrm{H}$ : Corporate Governance matters for dividend policy in the Indonesian finance industry.

\section{RESEARCH METHOD}

As mentioned above, this study investigates whether or not there are any differences in governance and characteristics between firms that pay dividend and firms that do not pay dividend. In addition, this study differentiates between dividend paid and dividend not paid companies using company age, size, leverage and profitability. This study uses companies classified as the finance industry and listed on the Indonesian capital market. Due to unavailability of data, the final sample of this study is 26 companies for the 2009 to 2014 period. Data was collected from financial reports, annual reports and other company information gathered from the IDX website, company website and other electronic sources. Dividend policy is measured by dividend per share divided by earnings per share. Board size is the number of supervisory board members in a company [42, 43]. Board independence is measured by the number of independent supervisory board members divided by total number of supervisory board members [44]. Managerial ownership is measured by a dummy. Total assets is used to measure company size [45, 46]. In this study, company age is the number of years since a company started its business [47]. The present study uses firm leverage which uses total debt divided by total assets as proxy $[48,49]$. Finally, firm profitability is measured by net income divided by total assets. The independent sample t-test is used to test the hypothesis.

\section{EMPIRICAL RESULT}

Having discussed the research method, this section explains the result and findings. Empirical research begins with a statistic descriptive. Dividend policy is measured by dividend per share divided by earnings per share. In the sample, there are companies that did not pay dividend during the observation. Dividend pay- out mean is $10.63 \%$, which means that for every $\mathrm{Rp} 1$, earnings paid to the shareholder is Rp. 0.1063. The maximum value of dividend pay-out is $55 \%$ with minimum value of $0 \%$, compared to previous studies, where it is $18.6 \%$ (Adjaoud and Ben-Amar, 2010) and 36\% [3]. In addition, it can be concluded that the dividend pay-out value for Indonesia's companies is lower than Australia [3]; it therefore confirms the finding of [11] that countries which have adapted French civil law tend to pay less dividend than countries which have 
implemented common civil law, like Australia.

The second variable is managerial ownership. The maximum value of managerial ownership is one and zero for minimum value. The average number is 0.3013 which means that only $30.13 \%$ of the sample have managerial ownership and the rest do not. Supervisory Board size has a maximum number of 13 and a minimum number of five board members. In addition, the average number of board members is seven persons. Indonesia's board size (average) is a bit lower compared to the finding of [36] who found $9.48 \%$ for South Africa, $8.6 \%$ for Nigeria, $7.98 \%$ for Kenya and $8.7 \%$ for Ghana. Mean value of board independence in this study is $31.06 \%$ with the minimum and maximum values of $13 \%$ and $50 \%$, respectively. This finding differs from a prior study done by [36] who obtained a mean value of $61.9 \%$ for board independence for South Africa, $87.83 \%$ for Negeria, $84.76 \%$ for Kenya and $27.01 \%$ for Ghana. The average board independence for the four countries (Sub-Saharan Africa) is $65.37 \%$ which is significantly higher compared to Indonesia (31.06\%). Mean value of company age is 42.73 years with minimum and maximum values of 15 and 119 years, respectively. Average values of company size, leverage and profitability are Rp. 99,672 billion, $68.04 \%$ and $2.06 \%$, respectively. Details of minimum, maximum, mean and standard deviation values are demonstrated in Table 1 below.

Table 1: Descriptive Statistics of Research Variables

\begin{tabular}{lllll}
\hline Variables & Min & Max & Mean & SD \\
\hline DP (\%) & 0.00 & 55.00 & 10.63 & 14.97 \\
MO (dummy) & 0,00 & 1.00 & 0.30 & 0.46 \\
BS (Person) & 5.00 & 13.00 & 6.98 & 11.78 \\
BI(\%) & 13.00 & 50.00 & 31.06 & 11.98 \\
CA (years) & 15.00 & 119.00 & 42.73 & 23.22 \\
CS & 0.19 & 855,04 & 99,67 & 174,96 \\
(Rp.billion) & & & & \\
CL (\%) & 10.00 & 98.00 & 68.04 & 30.48 \\
CP $(\%)$ & -7.88 & 28.00 & 2.06 & 32.37 \\
\hline
\end{tabular}

Notes: $\mathrm{DP}=$ Dividend policy, $\mathrm{MO}=$ Managerial ownership, $\mathrm{BS}=$ board size, $\mathrm{BI}=$ board independent, $\mathrm{CA}=$ Company age, $\mathrm{CS}=$ Company size, $\mathrm{CL}=$ Company leverage, $\mathrm{CP}=$ Company profitability.

The result of mean values for dividend paid and not paid is shown in Table 1. Compared to firms that paid dividend (0.250), firms that did not pay dividend have a high managerial ownership (0.337). The test indicates that there is a significant difference of managerial ownership between dividend paid and dividend not paid. Companies that paid dividend have larger board size (7.141) compared to companies that did not pay dividend (6.869). In addition, the test also indicates that there is a significant difference of board size between dividend paid and dividend not paid companies. Futhermore, firms that paid dividend have a slightly higher board independence $(31.7 \%)$ compared to firms that did not pay dividend (30.6\%). However, the difference is not significant.
Table 2: Mean value of Dividend Unpaid and Dividend Paid

\begin{tabular}{lllll}
\hline $\begin{array}{l}\text { Variab } \\
\text { le }\end{array}$ & $\begin{array}{l}\text { Dividend } \\
\text { Unpaid }\end{array}$ & \multicolumn{2}{l}{$\begin{array}{l}\text { Dividen } \\
\text { d Paid }\end{array}$} & Difference \\
\hline & O Mean SD & $\begin{array}{l}\text { O } \\
\text { Mea SD }\end{array}$ & F & Sig \\
bs & bs & n & stat & \\
\hline
\end{tabular}

Governance's

Characteristics

$\begin{array}{lllllllll}\text { MO } & 92 & 0.34 & 0.48 & 64 & 0.25 & 0.44 & \begin{array}{l}5.7 \\ 8\end{array} & \begin{array}{l}0.017 * \\ * *\end{array}\end{array}$

$\begin{array}{lllllllll}\text { BS } & 92 & 6.87 & 0.94 & 64 & 7.14 & 1.45 & \begin{array}{l}10 . \\ 30\end{array} & \begin{array}{l}0.022^{*} \\ *\end{array} \\ \text { BI } & 92 & 0.31 & 0.31 & 64 & 0.32 & 0.12 & 0.1 & 0.715\end{array}$

Firm's

Characteristics

$\begin{array}{lllllllll}\text { CA } & 92 & 43.48 & 24.1 & 64 & 41.7 & 21.9 & 0.4 & 0.695 \\ & & & 4 & & 3 & 8 & 7 & \\ \text { CS } & 92 & 101,5 & 182, & 64 & 96,9 & 165, & 0.0 & 0.893 \\ & & 9 & 15 & & 2 & 46 & 6 & \\ \text { CL } & 92 & 0.67 & 0.14 & 64 & 0.69 & 0.29 & 1.1 & 0.278 \\ & & & & & & & 9 & \\ \text { CP } & 92 & 1.90 & 2.36 & 64 & 2.30 & 4.20 & \begin{array}{l}2.9 \\ 9\end{array} & 0.086^{*} \\ & & & & & & & 9 & \end{array}$

Result of Independent Difference Test

Notes: $\mathrm{MO}=$ Managerial ownership, $\mathrm{BS}=$ board size, $\mathrm{BI}=$ board independent, $\mathrm{CA}=$ Company age, $\mathrm{CS}=$ Company size, $\mathrm{CL}=$ Company leverage, $\mathrm{CP}=$ Company Profitability $* * *, * *$, and $*$ is significant at $1 \%, 5 \%$, and $10 \%$.

From firm characteristics, it can be concluded that younger firms are likely to pay dividend compared to older firms. Regarding company size, the small firms tend to pay dividend as opposed to the big firms. This result contradicts the prior study of [22] which found that big size companies tend to pay dividend. However, higher leveraged firms paid dividend compared to low leveraged firms. This result does not concur with the finding of prior research of [3], which found that companies with higher leverage paid lower dividend. Finally, high profitability firms tend to pay dividend compared to low profitability firms. This finding is consistent with [22]. Among the variables used to represent firm characteristics, only company profitability shows a significant difference between dividend paid and dividend not paid. Managerial ownership matters for dividend policy due to the significant difference between companies that paid dividend and companies that did not. Companies that have low managerial ownership tend to pay dividend. This finding is aligned with the convergence governance hypothesis [39] where managerial ownership is an important incentive for managers to have the same interests as shareholders. However, it does not hold after ownership exceeds a certain limit that can make managers more powerful (entrenchment hypothesis) [40]. Besides, this study is consistent with [41] and [26] who concluded that managerial ownership matters for dividend policy. 
Board size also matters for dividend policy. The result shows that there is a significant difference between companies that paid dividend and companies that did not. Companies with a larger board size are likely to pay dividend. This finding is consistent with a study by [36] and it also confirms the resource dependence theory [33]. A large board tends to provide the company with diversity in terms of expertise, experience and knowledge of its members. This diversity will affect the judgment of the Supervisory Board so that the monitoring will be effective. The third significant difference is company profitability. The result is that companies with high profitability tend to pay dividend. The possible explanation is that high profitability companies are likely to have available cashflow to pay dividend. This finding is aligned with the finding of [36], especially for Nigeria and Ghana, where higher profitability companies tend to pay dividend.

\section{CONCLUSION AND RECOMMENDATION}

Dividend policy and corporate governance are two areas which are continuously being researched. However, there is a lack of studies done in countries that have adopted the French civil law, especially in Indonesia. Indonesia, with its unique governance system, can enrich the corporate governance literature. Therefore, this study investigates whether corporate governance matters for the dividend policy. By using 26 companies operating in the finance industry, it can be concluded that corporate governance matters for the dividend policy of Indonesian companies. To reduce the substitute hypothesis [11] and the retrenchment hypothesis [40], company monitoring must be effective. This study suggests that future research focuses on the regression between dividend policy and governance variables.

\section{AKNOWLEDGEMENT}

we thanks to the Rector of Universitas Bung Hatta and Universitas Putra Indonesia YPTK for significant supporting in term of finance and others. We also thank to reviewer for constructive comments.

\section{REFERENCES}

[1] Mehdi M, Sahut J-M, Teulon F. Do corporate governance and ownership structure impact dividend policy in emerging market during financial crisis? J Appl Account Res [Internet]. 2017;18(3):274-97. Available from:

http://www.emeraldinsight.com/doi/10.1108/JAAR-07-2014-0079.

[2] Miller MH, Modigliani F. Dividend policy, growth, and the valuation of shares. J Bus. 1961;34(4):411-33.

[3] Yarram SR, Dollery B. Corporate governance and financial policies: Influence of board characteristics on the dividend policy of Australian firms. Manag Financ. 2015;41(3):267-85.

[4] Bhattacharya S. Imperfect Information,Dividend Policy, and "The bird in the hand" Fallacy. Bell J Econ. 1979;10(1):259-70.

[5] John K, Williams J. Dividends, dilution, and taxes: A signalling equilibrium. J Finance. 1985;40(4):1053-70.

[6] Miller MH, Rock K. Dividend Policy under Asymmetric Information. J Finance. 1985;40(4):1031-51.

[7] Jensen M, Meckling W. Theory of the firm: managerial behavior, agency costs, and ownership structure. $\mathrm{J}$ financ econ [Internet]. 1976;3(4):305-60. Available from: http://ebooks.cambridge.org/ref/id/CBO9780511817410A032
[8] Jensen MC. Agency costs of free cash flow, corporate finance, and takeovers. Am Econ Rev [Internet]. 1986;76(2):323-9. Available from: http://www.jstor.org/stable/1818789

[9] Easterbrook FH. Two Agency-Cost Explanations of Dividends. AmEcon Rev. 1984;74(4):650-9.

[10] Rozeff MS. Growth, Beta and Agency Costs As Determinants of Dividend Payout Ratios. Vol. 5, Journal of Financial Research. 1982. p. 249-59.

[11] La Porta R, Lopez-de-Silanes F, Shleifer A, Vishny R. Investor Protection and Corporate Governance. J financ econ. 2000;58:3-27.

[12] John K, Knyazeva A. Payout Policy, Agency Conflicts, and Corporate Governance [Internet]. SSRN Electronic Journal. 2006. Available from: http://www.ssrn.com/abstract $=841064$

[13] Al-Najjar B, Kilincarslan E. Corporate dividend decisions and dividend smoothing. Int J Manag Financ [Internet]. 2017;13(3):304-31. Available from: http://www.emeraldinsight.com/doi/10.1108/IJMF-10-2016-0191.

[14] Nazri SNFSM, Smith M, Ismail Z. The impact of ethnicity on auditor choice: Malaysian evidence. Asian Rev Account. 2012;20(3):198-221.

[15] Adjaoud F, Ben-amar W. Corporate Governance and Dividend Policy: Shareholders ' Protection or Expropriation? J Bus Financ Account. 2010;37(5\&6):648-67.

[16] Brown P, Beekes W, Verhoeven P. Corporate governance, accounting and finance: A review. Account Financ. 2011;51(1):96-172.

[17] Baker HK, Powell GE. Dividend policy in Indonesia: survey evidence from executives. J Asia Bus Stud. 2012;6(1):79-92.

[18] Hasan T, Kadapakkam P-R, Kumar PC. Firm Investments and Corporate Governance in Asian Emerging Markets '. Multinatl Financ J. 2008;12(1):21-44.

[19] Ilona D. Directors' Diversity, Ownership Concentration and company performance in Indonesia listed companies. Universiti Utara Malaysia; 2015.

[20] Gordon MJ. Optimal investment and financing policy. J Finance. 1963;18(2):1963.

[21] Lintner J. Dividends, Earnings, Leverage, Stock Prices and the Supply of Capital to Coporations. Rev Econ Stat. 1962;44(3):243-69.

[22] Adjaoud F, Hermassi N. the Impact of Corporate Governance Mechanisms on the Dividend Policy of Canadian Firms: Empirical Study. Int J Business, Accounting, Financ. 2017;11(1):90-106.

[23] Elmagrhi MH, Ntim CG, Crossley RM, Malagila JK, Fosu S, Vu T V. Corporate governance and dividend pay-out policy in UK listed SMEs. Int J Account Inf Manag [Internet]. 2017;25(4):459-83. Available from: http://www.emeraldinsight.com/doi/10.1108/IJAIM-02-2017-0020

[24] Brockman P, Unlu E. Dividend policy, creditor rights, and the agency costs of debt. J financ econ. 2009;92(2):276-99.

[25] Renneboog L, Trojanowski G. Control structures and payout policy. Manag Financ. 2007;33(1):43-64.

[26] Fenn GW, Liang N. Corporate payout policy andmanagerial stock incentives. J financ econ. 2001;60(1):45-72.

[27] Gan J, Lemmon M, Wang M. Can firms build capital-market reputation to substitute for poor investor protection? Evidence from dividend policies, Working paper. 2011.

[28] Berle AA, Means GC. The modern corporation and private property Macmillan, New York, NY; 1932.

[29] Fukuyama F. Social Capital and the Global Economy. Foreign Aff. 1995;74(5):89-103.

[30] Denis DK. Twenty-five years of corporate governance research... and counting. Rev Financ Stud. 2001;10(3):191-212.

[31] Fama EF, Jensen MC. Separation of Ownership and Control Separation of Ownership and Control. J law Econ. 1983;26(2):301-25.

[32] Li M, Roberts H. Does mandated independence improve firm performance? Evidence from New Zealand. Pacific Account Rev. 2018;30(1).

[33] Pfeffer J. Size and Composition of Corporate Boards of Directors: The Organization and its Environment. Adm Sci Q [Internet]. 1972;17(2):218-28. Available from: http://www.jstor.org/stable/2393956\%5Cnhttp://about.jstor.org/ter ms

[34] Zahra SA, Pearce JA. Boards of directors and corporate financial performance: A review and integrative model. J Manage. 1989;15(2):291-334.

[35] Yermack D. Higher market valuation of companies with a small board of directors. J financ econ. 1996;40:185-211.

[36] Abor J, Fiador V. Does corporate governance explain dividend policy in Sub-Saharan Africa? Int J Law Manag. 2013;55(3):201-25.

[37] Benjamin SJ, Zain MM. Corporate governance and dividends payout: are they substitutes or complementary? J Asia Bus Stud. 2015;9(2):177-149. 
[38] Jensen MC. The Modern Industrial Revolution , Exit , and the Failure of Internal Control Systems. J Finance. 1993;48(3):831-80.

[39] Jung K, Kwon SY. Ownership structure and earnings informativeness: Evidence from Korea. Int J Account. 2002;37(3):301-25.

[40] Morck R, Shleifer A, Vishny RW. Management Ownership and Marekt Valuation: and empirical analysis. $J$ financ econ. 1988;20:293-315.

[41] Short H, Keasey K, Duxbury D. Capital Structure , Management Ownership and Large External Shareholders : A UK Analysis. Int J Econ Bus. 2002;9(3):375-99.

[42] Bozec R. Boards of Directors , Market Discipline and Firm Performance. J Bus Financ Account. 2005;32(9):1921-60.

[43] Cheng S. Board size and the variability of corporate performance. J financ econ. 2008;87(1):157-76.

[44] Lefort F, Urzúa F. Board independence, firm performance and ownership concentration: Evidence from Chile. J Bus Res. 2008;61(6):615-22.

[45] Colpan AM, Yoshikawa T. Performance Sensitivity of Executive Pay: The Role of Foreign Investors and Affiliated Directors in Japan. Corp Gov An Int Rev. 2012;20(6):547-61.

[46] Zaitul, Ilona D. Gender in Audit Committee and Financial Reporting Timeliness: the Case of Unique Continental European Model. Int J Eng Technol. 2018;7(2.29):436-42.

[47] Arosa B, Iturralde T, Maseda A. Ownership structure and firm performance in non-listed firms: Evidence from Spain. J Fam Bus Strateg [Internet]. 2010;1(2):88-96. Available from: http://dx.doi.org/10.1016/j.jfbs.2010.03.001

[48] Mak YT, Kusnadi Y. Size really matters: Further evidence on the negative relationship between board size and firm value. Pacific Basin Financ J. 2005;13(3):301-18.

[49] Foong S-Y, Idris R. Leverage, product diversity and performance of general insurers in Malaysia. J Risk Financ. 2012;13(4):347-61.

\section{AUTHORS POFILE}

My name is Zaitul, I am attached with Economics Faculty, Universitas Bung Hatta, Indonesia my area of interest is corporate finance and corporate governance.

My name is Muhammad Ridwan, Economics Faculty, Universitas Putra Indonesia YPTK, Indonesia my area of interest of corporate finance and corporate governance.

My name is Hanna Pratiwi, Economics Faculty, Universitas Putra Indonesia YPTK, Indonesia and my area of interest is corporate finance and corporate governance. 